Article

\title{
Evaluations of the Roles of Organizational Support, Organizational Norms and Organizational Learning for Adopting Environmentally Friendly Technologies: A Case of Kiwifruit Farmers' Cooperatives of Meixian, China
}

\author{
Hongyu Wang ${ }^{1,2,+} \mathbb{D}$, Apurbo Sarkar ${ }^{1,+}$ and Lu Qian ${ }^{1, *(\mathbb{D})}$ \\ 1 College of Economics \& Management, Northwest A\&F University, Yangling 712100, Shanxi, China; \\ wanghongyu@nwafu.edu.cn (H.W.); apurbo@nwafu.edu.cn (A.S.) \\ 2 The Sixth Industry Research Institute, Northwest A\&F University, Yangling 712100, Shanxi, China \\ * Correspondence: luqian@nwafu.edu.cn \\ + These authors contributed equally to work.
}

\section{check for} updates

Citation: Wang, H.; Sarkar, A.; Qian, L. Evaluations of the Roles of Organizational Support,

Organizational Norms and

Organizational Learning for Adopting Environmentally Friendly Technologies: A Case of Kiwifruit Farmers' Cooperatives of Meixian, China. Land 2021, 10, 284. https:// doi.org/10.3390/land10030284

Academic Editor: Ilaria Rodella

Received: 19 February 2021

Accepted: 8 March 2021

Published: 10 March 2021

Publisher's Note: MDPI stays neutral with regard to jurisdictional claims in published maps and institutional affiliations.

Copyright: (c) 2021 by the authors. Licensee MDPI, Basel, Switzerland. This article is an open access article distributed under the terms and conditions of the Creative Commons Attribution (CC BY) license (https:// creativecommons.org/licenses/by/ $4.0 /)$.

\begin{abstract}
Environmentally friendly technologies have long been recognized as a widespread phenomenon working within the functions and performance of farms. Farmer's cooperative organization might profoundly foster the environmentally friendly technologies (EFT) and availing competitive advantage to the farmer. Illustrated by the natural-resource-based view of the farm (NRBV), this study examined the influence of organizational support, organizational norms, and organizational learning on adopting EFT and proposed a model quantifying the impacts of these approaches towards availing competitive capabilities (i.e., cost, quality, flexibility, and delivery). The framework is empirically endorsed by employing the partial least squares approach to structural equation modeling (PLS-SEM) with the help of a household survey from a spectrum of 292 farmers of 38 kiwifruit cooperatives of Meixian County, China, from August to September 2020. The findings demonstrate that organizational support, organizational norms, and organizational learning positively influence EFT. Moreover, the study found EFT positively impacts product cost, product quality, product delivery, and production flexibility. Interestingly, the relationship between the adoption of environmentally friendly technologies and the competitive capabilities of kiwifruit farmers of Meixian is positively significant. The study proposes several policy recommendations emphasizing the role of organizations in the form of farmer's cooperatives in boosting farmers to engage in proenvironmental behavior and, therefore, shifting the trends of future research directions on the adoption of environmentally friendly technologies.
\end{abstract}

Keywords: adoption; impacts; bootstrapping; agricultural cooperatives; organization participation; environmentally friendly technologies

\section{Introduction}

Agricultural sectors are facing numerous challenges during the 21st century because they need to provide additional food and fiber to support the ever-increasing population with very limited natural resources and far less rural labor which affect the overall growth of many developing countries mainly depending upon agriculture and demanding the adoption of more productive environmentally friendly technology in response to global warming, climate change and landfill problems [1,2]. In recent times, impressive technological advancements have been traced within the agriculture sector, which possessed a significant increase in productivity and efficiency, especially for supporting "the Green movement started in the early 1950s". The prime issue that emphasizes massive attention among government, international organizations, and academia is minimizing the use of valuable resources to ensure maximum output, provide enough support towards society, and secure environmental safety [3]. Almost every sector faces the dilemma of utilizing 
resources to capture the maximum output while facilitating less pollution. The sector which can make a proper balance among input, output, and emission, can foster competitiveness. Technology and competitiveness have become the most common mottos of modern times [4]. As the global transition holds staggering changes, technologies play a decisive role in fostering competition and development on micro and macroeconomic levels [5]. Competitiveness means the advantages that any entities enjoy when they are facing competitions or the special capabilities which provide the entities with a better stand than their competitors [6,7]. On the other hand, environmentally friendly technology is such technological transition by which the viable production growth can be secured while harming the environmental components less, such as water, air and land [8,9]. Shrivastava [10] defined environmentally friendly technologies as the production tools, processes, actions, system designs, and procurement mechanisms that allocate the resources, limit the environmental degradation and foster the sound ecosystems. These can provide facilities such as emissions prevention, environmental assessment and sustainable farming mechanisms, which further includes supporting strategies like waste disposal procedures (composting, biogas) and low synthetic input (organic fertilizers and pesticides) oriented agriculture systems [11]. Food and Agriculture Organization of the United Nations (FAO) defines EVT as a set of integrated tactics which can allow the producer with the power of pollution control, proper utilization of waste, enable resource efficiencies, and foster the socioeconomic viabilities of the farmers [12].

However, the adoption of environmentally friendly technology in agriculture differs significantly throughout various territories and agricultural practices [13]. The adoption rate and tendencies among the smallholder farmers of developing countries of Asia and African unions have been traced relatively low [14-17] and eventually limit their ability to enjoy the staggering advantages for enhanced agro-production, efficiency and opportunity to lead a better livelihood $[18,19]$. It is identical that well-structured agricultural transitions within the regions which tend to lower adoption rate fades away for tackling its economic, social, and ecological aspects and eventually indulge themselves into threatening condition for mitigating food security and poverty alleviation [20]. Mostly, smallholder farmers in developing countries are not financially strong enough to bear the initial investments of accessing new technologies as well as the poor access of information, technical know-how, and weak negotiation abilities are also creating a burden for accessing new technologies, resulting in weak efficacy. These are including all associated costs for finding appropriate technologies to adopt, priority costs for initiating negotiations with suppliers and imposing contract assessment [21,22], which eventually hinders the agricultural efficiency [23,24].

For the elimination of the above-mentioned barriers, cooperatives organizations could act as a blessing for the smallholder farmers $[13,25,26]$. Cooperatives exist across most sectors of the economy and promote entrepreneurship, democratization, and the building of communities. Cooperatives are not charities $[27,28]$; rather, they are an organized group of self-help entrepreneurs who want to make a difference in their communities and region [29,30]. According to Birchall [31], the history of cooperatives is full of evidence of their ability to increase their members' incomes, decrease the risks they run, and enable them to become full participants in civic society. They have been especially impactful for securing smooth development in rural and regional areas. Around the world, cooperatives have played and continue to play an important role in helping people and small businesses to organize and foster better conditions and enable disparate groups to compete more favorably against larger industry players such as major corporations. In doing so, they have helped to promote greater equality within society, a role that is especially important at a time when digital transformations and modern forms of capitalism have tended to result in a concentration of power and greater disparity. The cooperatives promote exchange of knowledge between different farmers through organizational learning and raise the level of awareness of farmers. Activities undertaken by cooperatives today are playing an increasingly larger and important role in developing and emerging countries, especially for a society like China that attaches great importance to blood, 
kinship, and geography, members of the network can achieve adequate circulation and sharing of information through a mutual contact to exchange the ideas and concepts. In China, cooperatives in various forms have existed for almost 100 years. Since the 1990s, China's agricultural agro-based cooperatives have flourished. This is mainly because local governments are now promoting the development of industrial organizations, which is an administrative requirement.

While organizing cooperatives has been largely an 'economic' and community building movement, they have also served other roles. For example, historically, the 'Gung Ho" Gōnghé," meaning 'work together') industrial cooperatives movement in the 1930s started as a way to organize in order to increase production to aid in China's 'War of Resistance' against occupying Japanese forces. Since the 1980s a Chinese legal infrastructure and government support and encouragement have helped to encourage the growth of cooperatives and the economic development and community building they do. In modern China, there are hundreds of thousands of Chinese cooperatives, especially in the agricultural sector. According to the statistics of the Ministry of Agriculture and Rural Affairs, by the end of 2018, there were 417,000 agricultural-based industrialized organizations and 2.186 million farmers' cooperatives across the country, which led to nearly half of the country's farmers.

Cooperatives, however, have many inherent drawbacks. The opposite aspect of the freedom and collective governance is the fairly divided socioeconomic obligations of the participants making cooperative organizations relatively dynamic while maintaining various members' demands and expectations [32,33]. While the outsourced investments are unable to contribute towards the collective, the financial viabilities and risk impacts each and every participant. The shared responsibilities for covering risks that could cause expenses in the aggregate were very important. Maybe it may appear an inconvenient proposition for someone to share economic responsibility, but it is a challenge to be accepted in view of the advantages of collaboration [34]. Conversely, facilitating cooperatives requires the members of producer groups to satisfy their requirement. With respect to collaboration disadvantages, these are primarily the weakness of self-reliance in the decision-making process for the production of food raw materials on the farms. Another prime drawback of cooperatives is the complexities to transfer the equities within the generations [35,36]. It is hard for the farmers to stay faithful to the collective, particularly in the scenario in which corporations obtain negotiating power towards production decisions, purchasing raw materials and sharing risk [37,38].

Various research has revealed the staggering impacts of farmer cooperatives for fostering modern technology adoption [39-43]. In an evaluation of Ugandan agricultural cooperatives, Mugisha et al. [44] confirmed that cooperative organizations possessed a positive and effective contribution for enhancing farmers' adoption tendencies towards ecofriendly technologies. The research of Kehinde et al. [45] concluded that cooperative membership has a significant influence on the full adoption of improved technologies among cocoa-based farming systems of Southwestern Nigeria. Gong et al. [46] discovered that cooperative participation gives Chinese (Anhui province) family-based farmers better opportunities to gather in-depth information about innovative technologies and provides an advantageous place for exercising more productive and enhanced practices. By exploring the potentiality of information accessibility and capital endowment within cooperatives of Nigeria, Nwankwo et al. [47] revealed that cooperatives are a strong medium to disseminate information, technical know-how, and case studies. The study also found that the information gathered from cooperatives is more trustable and reliable than any other sources. The empirical investigation of Ma and Abdulai [48] confirmed that cooperative membership has an optimistic and substantial influence for exercising integrated pest management technologies and fostering efficiency resulting in a rise in net revenues and income. By evaluating a set of household data of rural Nigeria, Wossen et al. [49] confirmed that the cooperatives have greater encouragement power for adopting technology by facilitating credit access. Therefore, the participation of farmers in the cooperatives 
will have staggering impacts on the adoption behavior of farmers. However, farmer's cooperatives are widely considered as a well-structured organization facilitating farmers mostly by exercising organizational support [50-54], organizational norms [55-58], and organizational learning [59-63]. Theoretically organizational norms, organizational learning and organizational supports are crucial components of any organizational setup [64]. In cooperative organizational setup the evaluation of the role of organizational support, norms and learning could possess a staggering research value.

In spite of having profound pieces of literature on the role of participating in cooperatives on quantifying farmers' adoption of modern, innovative, and eco-friendly technologies, empirical evidence of how and to what extent cooperatives facilitate the technology adoption extensity, more specifically how the organizational support, norms and learning interconnected with each other, remains unclear. Moreover, there is minimal evidence that could be traced, which can highlight the impacts of these three aspects for fostering product cost, product quality, product delivery, and production flexibility and eventually availing competitive advantages. To address this knowledge gap, the study proposed an integrated framework of the interaction among organizational norms, supports and learning for facilitating the smooth adoption of environmentally friendly technologies (EFT). Moreover, we traced how the adoption of EFT facilitates the competitive advantages. The proposed framework was proved with the help of empirical data collected from 292 kiwifruit farmers' cooperative members of Meixian County, China, from August to September 2020. To the best of our knowledge, the interconnection of the organization's supports, norms, and learning in the agricultural dimensions would be one of the novel studies and major innovations of the study which further quantify the how the adoption of EFT facilitates the competitiveness among cooperative participants. The study will be helpful for the governmental agencies for availing smooth transition of EFT and provide a baseline for formulating effective policies, as the study intends to evaluate the role of organizational support, organizational norms and organizational learning for adopting environmentally friendly technologies.

\section{Methodology and Background of the Data}

\subsection{Methodology}

The design of the study was derived from a combined methodology of quantitative and qualitative approaches. The variables, indicators, and excerpt questionnaire items of the study were composed from an in-depth literature investigation, and the empirical parts of the study were obtained from survey data of 292 kiwifruit farmers. The model validation was done by structural equation modeling (SEM) tactics. More specifically, we analyzed the results using partial least square (PLS) of structural equation modeling (SEM), which is an estimation technique for the structural equations model that combines the econometric perspective with a focus on the prediction and modeling of latent variables, resulting in greater flexibility in theoretical modeling. The PLS-SEM is considered a multivariate tactic that broadly incorporates the existing knowledge with empirical settings and datadriven modeling [65]. The PLS-SEM has been considered as superior to other SEM tactics like covariant base (CB-SEM), GSCA, and NEUSREL, due to its flexibility to work with small datasets, compatible with little available theory, paramount predictive accuracy, and versatility of handling various models [66]. The tactics of PLS-SEM could be useful to envisage the latent dependent variables of the model by maximizing the explained variance (R2). The main advantages of this approach are that it allows for exploring possible relationships between constructs, and it does not require samples with a normal distribution $[67,68]$. As the agriculture sector is dynamic, and there is a hurdle to find normal sample data, PLS-SEM would be one of the best options as it does not need sample normalization. The PLS-SEM can be used in diversified fields as it assists the investigator to evaluate a complex relational modeling scenario with better accuracy and reliability, as suggested by Akter et al. [69], Sarkar et al. [70], and May et al. [67]. Several studies with similar dimensions also utilized the PLS-SEM to measure the effects of some certain 
activities, such as Mutyasira et al. [71], Ferraz et al. [72], May et al. [67], Guzmán et al. [73], and Idrus et al. [74].

The study adopted a three-step methodology to maintain profiling validity of model and content, as suggested by Dang et al. [75], Wong [66], and May et al. [67]. First, the variables and indicators were composed from an extensive literature review; in the second stage, a pilot test was done to find any conceptual inconsistency or bias content. After adjusting the questionnaire (as per the observations gathered from the pilot test) in the third stage, the study purified all the latent variables as per the factor loading and coefficient alphas. Upon achieving the content validity, the reliability of the measurement was identified by securing the indicator's reliability, internal consistency, convergent validity, and discriminant validity.

\subsection{Operationalization of Latent Variables}

The study considers of five latent variables, which are primly multidimensional, and it cannot compute within a single indicator. Therefore, the study utilized several indicators from the past literature for measuring each of the latent variables, as shown in Figure 1. The level in which members feel that the organization values their efforts, concerns for their health as well as addresses social, physiological, and social needs are considered as key indicators of organizational support [76]. The first three exogenous variables (Organizational support, Organizational Learning, and Organizational norms) of the model (a prime component of organizations) included the interactions of the organizations, and the three components could be important elements for the kiwifruit industries technology adoption [54]. Organizational supports (OS) could be derived from prospects of emotional support and instrumental support $[77,78]$. The well-known studies by Rhoades and Eisenberger [76] and Colbert et al. [77] were utilized to formulate the indicators OS_3, OS_4, OS_8 and OS_9. The indicators OS_1, OS_2, OS_5, and OS_6, were taken from the study of G. Xu et al. [54], and the indicator OS_7, OS_10 and OS_12 were chosen from Frambach and Schillewaert [79]. While the indicator number OS_11 is the authors' contribution. Organizational learning (OL) is characterized as the mechanism in which farmers gain information, show the adaptive behavior, and maximize their involvement in the organization by coordinating preparation, communications, and understanding from participants so that their viability, production, and advancement is sustained by the organization [54]. The indicators OL_2, OL_2,OL_3, and OL_5, were taken from the study of G. Xu et al. [54]. OL_6, OL_9, and OL_10 were from the studies of Jiménez-Jiménez and Sanz-Valle [80] and Deji [81], and the indicators OL_4 and OL_7 are the contributions of the authors. The organizational norm $(\mathrm{ON})$ is identified as the compliance with obligatory outer pressures and effective externalities of organizational culture, which increasingly includes the participant complying with the standard practices and then helping to achieve idealization. Indicators ON_1, ON_2,ON_3, ON_5, ON_6, ON_7, ON_8, and ON_9 were taken from G. Xu et al. [54], and indicators ON_4 and ON_10 are the author's contributions.

The three indicators (AD_1, AD_2 and AD_3) of the latent variables four (adoption of EFT) were taken from the relevant studies regarding adoption, e.g., Cakirli Akyüz and Theuvsen [82], Mutyasira et al. [71]. Finally, the indicators regarding competitiveness were taken from the study of Kumar Mittal and Singh Sangwan [83] and Cakirli Akyüz and Theuvsen [82]. Some of the excerpt questionnaire was not considered in the final study, as those have very low factor loadings within the pilot test phase. Based on the above discussion and extensive literature investigation, the study crafted four hypotheses:

H1: Organizational learning is positively correlated with farmers of cooperatives to adopt EFT.

H2: Organizational support is positively correlated with farmers of cooperatives to adopt EFT.

H3: Organizational norms are positively correlated with farmers of cooperatives to adopt EFT.

H4: The adoption of EFT positively influences to foster the competitiveness of the farm. 


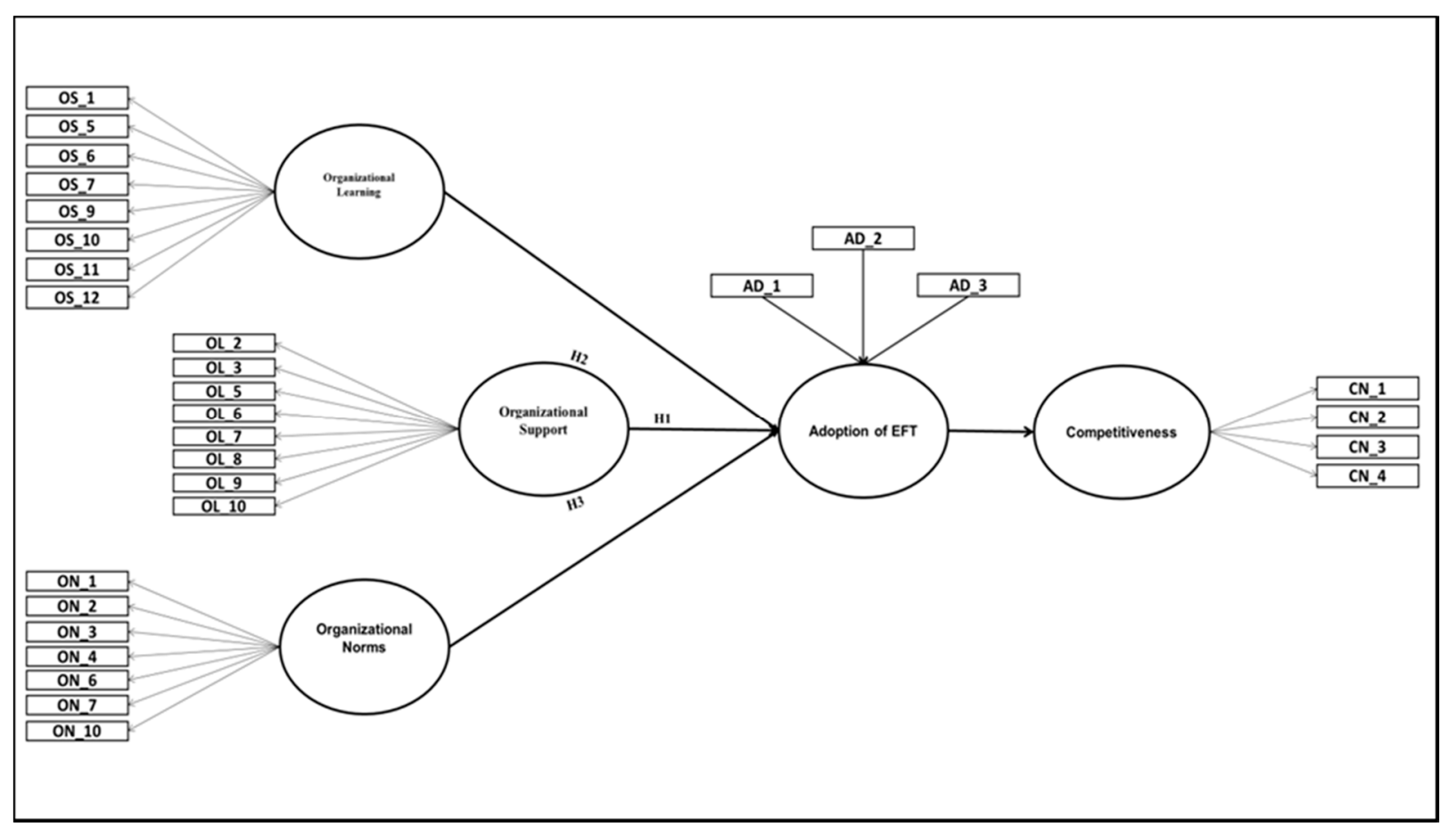

Figure 1. Conceptual model.

\subsection{Area of Data Collection}

The empirical data of the study was extracted from the kiwifruit framers of Meixian Country, Shaanxi Province, China. The province is well recognized as the birthplace of China's modern agricultural civilization, one of the most innovative agricultural provinces in China. In terms of the kiwifruit industries of Shaanxi, it accounts for about $40 \%$ of the country, ranking first in the country, and possessed unique advantages and foundation for the kiwifruit industry. Meixian is Shaanxi's beating heart for the development and expansion of modern kiwifruit cultivations. It is widely claimed that kiwifruit industries in China largely follow the illustration of Shaanxi, whereas the kiwifruit sectors of Shaanxi will follow the illustration of Meixian, which is blessed with the Qinling Mountain. Moreover, Meixian is located in the main region of the kiwifruit industries of Shaanxi, where the kiwifruit industries flourished 1200 years ago under the Tang dynasty. Currently, Meixian is enjoying significant growth in the kiwi sector, taking advantage of the precise benefits such as suitable locations, multiple valuable resources, strong technological infrastructure, and manufacturing standards. Meixian kiwi sector is currently covering 21,000 ha of land, which is accumulating one-third of Kiwi cultivable regions in Shaanxi, one-fifth in China, and one-tenth of global accumulation. The cumulative annual output of 460,000 tons and production price hit RMB 3000 million (USD 461.82 million), making Mei County the landmark region of Shaanxi and Chinese kiwifruit industries [84]. There are four distinct key points which provide Meixian tremendous advantage for maintaining the flourishing kiwifruit industry: (i) environmental circumstances, owing to the perfect location within north side of Qinling Mountain Qinling-Ba mountains regions, where, naturally sound conditions are present for kiwifruit yields; (ii) rich germplasm resources, the land near Qinling mountains are rich with high quality gene substances comprising various wild kiwifruit's gene properties, out of which there are 18 selective varieties and they breed with a wide variety of color and yielding periods; (iii) technological and knowledge advantages, Meixian is supported by from Yangling State Agricultural High-tech Demonstration Zone and Northwest A\&F University, which allows the entire production chain of the kiwifruit sector fully interconnected with technical and standardized framework for synthesis, planting, bandwidth, processing, research and development, and storing; (iv) facilities 
of well designed marketing, kiwifruit brands of Meixian are well-known, established by sector leaders and sales agents by incorporating an organic-based framework and food protection that provides the kiwifruit sector of Meixian with dynamic capabilities [85]. Meixian is also part of the "National Kiwifruit Standardized Production Demonstration Zone," "Top Ten County of Chinese Fruit and Vegetable Standardization Construction," and "China Kiwifruit Pollution-free Technology Demonstration County" [54]. Therefore, the study area is representative of kiwi production.

\subsection{Prospects of the Study}

Agriculture and rural development in Shanxi mostly replicate the scenario of the Chinese agrarian sector, which is largely dominated by the smallholding farmers. The agrarian sector of China is currently witnessing a larger labor migration rate resulting in the vulnerable situation to maintain the fast peace of economic transmission. As the small farming trend, income from agriculture cannot fully support the rural families. A large number of young farmers tend to migrate to city areas for seasonal or permanent work, as cities will provide wider opportunities for jobs as service and industrial sectors flourish in cities, whereas older individuals and women remain in rural areas as prime farm workers $[13,54]$.

The special framework of smallholders and shortage of rural labor is bridging staggering prospects towards the development of agricultural cooperatives which largely promote and invest low production input (e.g., land and capital) and trigger the adoption of several environmentally friendly technologies (e.g., harvesting, processing, and storage) [86]. Cooperatives can positively influence the transformation from labor-intensive farming structure to capital-intensive agriculture strategies, which is a gateway to rural modernization of Chinese agriculture. Especially after "the national farmer cooperative law" was introduced in 2007, the quantity of agricultural cooperatives in Meixian has amplified at an extraordinary stride. Meixain County is a prime kiwifruit demonstration zone of Shaanxi province and a key national cooperatives model desaturation zone as well. The cooperative of Meixian County has won some profound awards. For example, Qifeng Selenium Rich Kiwi Fruit Professional Cooperative was awarded as the top 100 Provincial Strong Demonstration Cooperatives by Provincial Cooperative in 2010 and National Cooperative Model by the Ministry of Agriculture of China in 2012. It is, therefore, appropriate to explore the connection among organizational learning, support, and norms in terms of facilitating the farmers' adoption of EFT, and data from Meixian would be representative.

\subsection{Data Collection}

We utilized multistage cross-sectional tactics for choosing the appropriate farmers for our study. First of all, we purposively selected 12 towns from 18 towns of Meixian, which has the greatest number of farmer's cooperatives and is a prime kiwifruit cultivation area. The general population of Meixian has 324,600 people. After that, we purposively selected six towns that have the greatest number of kiwifruit cooperatives. We further randomly selected 5-8 cooperatives each within those six towns, which comprised a total of 38 cooperatives mainly working on kiwifruit. We conducted a pilot test with randomly selected 50 farmers. Finally, we selected 8-12 members from each cooperative for covering diverse farmers, and a face-to-face interview was conducted with a randomly selected 430 members of those cooperatives. The empirical information was collected with a structured questionnaire from August to September 2020. As a multivariate tactic, PLS-SEM does not demand strict sample size and data normalization [87]; determining the appropriate sample size for producing an effective PLS-SEM model is a tricky question [66]. Hence, Hoyle [88] and Hair et al. [65] suggested that at least 100 observations could be the starting point for securing the path estimation. Interestingly, Marcoulides and Saunders [89] addressed that the minimum sample extent might be determined by the maximum number of arrows directing towards the latent variable. They suggested that if the maximum number of arrows counts as two, the minimum sample size should be 52. If the arrow number is five, then the sample should be 70 , and if the arrow count is 10 , then the 
minimum number of the sample should be composed of at least 91 observations. With the help of a structured questionnaire, we gathered 292 responses with full information (those do not contain any missing information). Therefore, the final data set of 292 farmers secured all the above-discussed parameters of minimum sample size. Moreover, Table 2 shows the Kurtosis and Skewness values are between \pm 1 , which confirms the data normality is within the acceptable limit. The design of the questionnaire was set as two parts: the first part demographic profile of the respondent was gathered and the second part of the questionnaire was a 5 points Likert scale where 1 denotes strongly disagree, 2 disagree, three neutral, 4 agree to some extent, and 5 means strongly agree (excerpt questionnaire used in the study is demonstrated in Table 1, Appendix B). Particularly, we evaluated the data regarding the adoption of environmentally friendly technologies (production and post-harvest).

\section{Estimation Procedure}

In SEM, two distinct categories of measurement scale are present; (i) formative and (ii) reflective. In cases with strong correlations and interchangeability of measures, the reliability and validity of measures should be carefully evaluated $[65,70]$. In the course of the study, we utilized the reflective measurement scale. The estimation of the process of the study was composed of two stages. Partial least squares structural equation modeling (PLS-SEM) was in the first stage to examine to what extent the three constructs (organizational support, organizational values, and organizational norms) derived the adoption of EFT. In the context of the study, the adoptions of EFT are latent variables which are directly unobservable. As an alternative, a set of excerpt questionnaires was used as indicators for the fundamental latent variables. The SEM model encompasses an outer model that identifies the interrelationship among the latent factors and underlined indicators, and an inner model comprised the interrelationships among the dependent factors and independent latent factors highlighting the path coefficients of those factors [66]. The second stage comprised a model that quantifies to what extent the adoption of EFT led the competitiveness in the form of cost reduction, maintaining high-quality production, efficient delivery, and production flexibility. For the prospects with the study, we added independent variables in the SEM model explained earlier, which is synthesized with the theory of competitive advantages and akin research [90-93]. Figure 1 denotes the combined model used in the study.

\section{Results}

This section stated the results attained after analyzing the questionnaire. First of all, we described the demographic information of the sample, followed by a procedure to estimate the common method bias. After that, the results of the PLS-SEM comprised four phases: reliability and validity test, measurement model, structural model, and checking structural path significance in bootstrapping.

\subsection{Demographic Profile}

The kiwifruit farmers studied in the research were on average 37 years old (SD = 5.8), $77 \%$ of them are male, most of them have at least primary education (37\%), $22 \%$ of the farmers has high school degree, only $13 \%$ of them are undergraduate or above and the remaining $22 \%$ are illiterate. Moreover, we found most of the farmers used production/preharvest environmentally friendly technology $(67 \%)$. Nearly $88 \%$ of the EFT has been introduced to them by cooperatives, and the rests of the farmers were aware of the EFT before joining the cooperatives. Descriptive statistics of key variables are stated in Table 1. 
Table 1. Descriptive statistics of key variables.

\begin{tabular}{|c|c|c|c|}
\hline Constructs & Variables & Mean & Standard Deviation \\
\hline \multirow{8}{*}{ 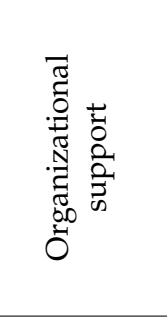 } & OS_1 & 2.66 & 0.67 \\
\hline & OS_5 & 3.35 & 0.95 \\
\hline & OS_6 & 3.46 & 0.95 \\
\hline & OS_7 & 4.40 & 0.61 \\
\hline & OS_9 & 3.95 & 0.78 \\
\hline & OS_10 & 3.74 & 1.01 \\
\hline & OS_11 & 3.27 & 1.13 \\
\hline & OS_12 & 4.13 & 1.36 \\
\hline \multirow{8}{*}{ 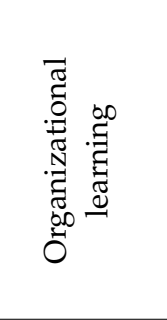 } & OL_2 & 3.55 & 0.89 \\
\hline & OL_3 & 3.56 & 0.92 \\
\hline & OL_5 & 3.53 & 1.03 \\
\hline & OL_6 & 2.17 & 1.08 \\
\hline & OL_7 & 3.04 & 1.24 \\
\hline & OL_8 & 4.36 & 0.61 \\
\hline & OL_9 & 4.11 & 0.69 \\
\hline & OL_10 & 4.42 & 0.57 \\
\hline \multirow{7}{*}{ 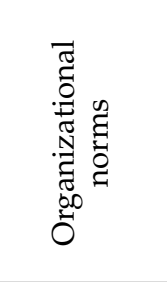 } & ON_1 & 3.62 & 0.90 \\
\hline & ON_2 & 3.82 & 0.83 \\
\hline & ON_3 & 3.62 & 0.83 \\
\hline & ON_4 & 3.67 & 0.92 \\
\hline & ON_6 & 3.71 & 0.97 \\
\hline & ON_7 & 3.81 & 0.88 \\
\hline & ON_10 & 4.04 & 0.62 \\
\hline \multirow{3}{*}{$\begin{array}{l}\frac{1}{0} \\
\frac{0}{2} \\
\frac{0}{4}\end{array}$} & AD_1 & 3.87 & 0.82 \\
\hline & AD_2 & 4.18 & 0.79 \\
\hline & AD_3 & 4.03 & 0.92 \\
\hline \multirow{4}{*}{ 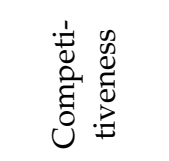 } & CN_1 & 4.08 & 0.62 \\
\hline & CN_2 & 4.17 & 0.61 \\
\hline & CN_3 & 4.08 & 0.69 \\
\hline & $\mathrm{CN}_{-} 4$ & 4.21 & 0.71 \\
\hline
\end{tabular}

\subsection{Common Method Bias Test}

Since all of the indicators in the study were estimated by distinct types of respondents (farmers from the kiwifruit cooperatives), we utilized a five-point Likert scale for evaluating the empirical data; a typical procedural prejudice might therefore rise. Therefore, the weight of the common method bias was substantially assessed. Interestingly, due to the lack of unified forecasting tactics for mapping the effects of common method bias [94], the study comprised a dual phases method for dealing with the concerns of common bias, i.e., Harman's single-factor test and correlation matrix procedure (Please see Appendix B). The summary of Table A3 portraits associated data is free from single factor bias issues, and the values of the first factors also did not lead to the most variance (please see Appendix B). As this investigation did not find the problem of common method bias, the dataset is therefore valid for further evaluation.

\subsection{Results from the PLS-SEM Approach}

For assessing the PLS-SEM approaches, the study utilized the procedure of (i) explanation of target endogenous variable variance, (ii) inner model path coefficient sizes and significance, (iii) outer model loadings and significance, (iv) indicator reliability, (iv) internal consistency reliability, (v) convergent validity, (vi) discriminant validity, (vii) bias test, and (viii) checking structural path significance in bootstrapping as suggested by Wong [66], May et al. [67], and Munim and Noor [95]. 


\subsubsection{Measurement Model}

The assessment of the results of the study starts with the evaluation of the measurement model. The measurement model produced by the data revealed in Figure 2 stated the interrelationship on how all the latent variables are quantified by the observed variables. According to Wong [66] and Sarkar et al. [70], for providing a smooth transition and quantifying a reliable and valid PLS-SEM model, indicator reliability, internal consistency reliability, convergent validity, and discriminant validity could be measured and average variance extracted (AVE). Table 2 summarizes the outcome that showed the reliability and validity of the model. Table 2 denotes the standardized factor loadings of the CFA framework, all of which were statistically viable $(p$-value $<0.001)$, representing that the variables replicate their fundamental latent paradigm. This endorses the convergent validity of the framework, as suggested by Anderson and Gerbing [96]. Table 2 also represents the Cronbach's alpha, composite reliability (C.R.), and average variance extracted (AVE) of all the indicators. The Cronbach's alpha value of all the indicators passed the accepted value 0.4 and were close to the preferred value of 0.7 [48]. The C.R. was crafted by utilizing the following equation suggested by Hair et al. [97]:

$$
C R=\frac{\left(\sum_{i=1}^{n} f l_{1}\right)^{2}}{\left(\sum_{i=1}^{n} f l_{1}\right)^{2}+\left(\sum_{i=1}^{n} M E_{1}\right)}
$$

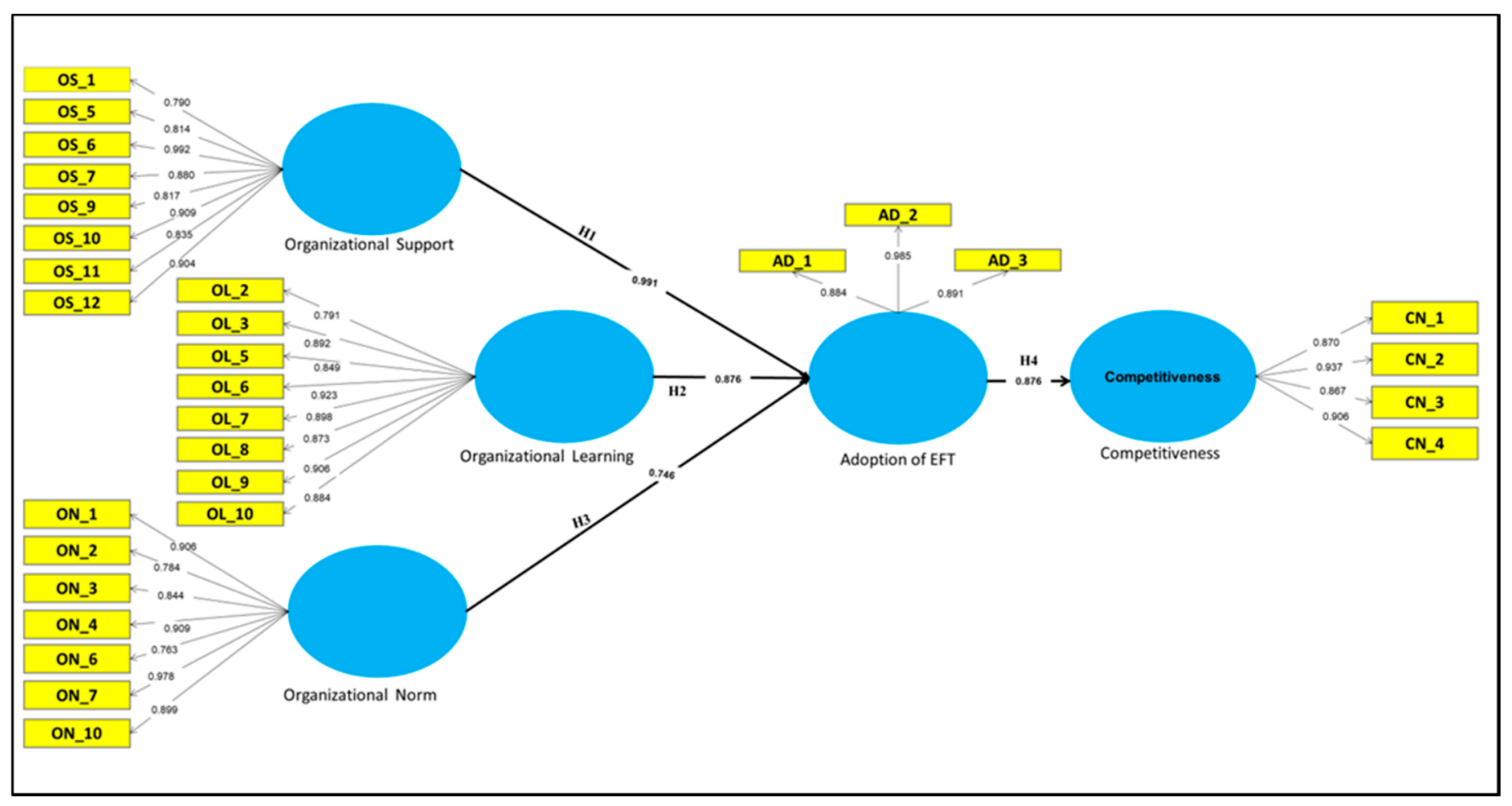

Figure 2. PLS-SEM results of the proposed model. 
Table 2. Validity of constructs (reflective outer models).

\begin{tabular}{|c|c|c|c|c|c|}
\hline Constructs & Variables & Loadings & $\begin{array}{c}\text { Indicator } \\
\text { Reliability }(\lambda)\end{array}$ & $\begin{array}{l}\text { Composite } \\
\text { Reliability }\end{array}$ & AVE \\
\hline \multirow{8}{*}{ 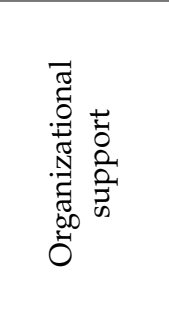 } & OS_1 & 0.790 & 0.624 & \multirow{8}{*}{0.898} & \multirow{8}{*}{0.757} \\
\hline & OS_5 & 0.814 & 0.663 & & \\
\hline & OS_6 & 0.992 & 0.984 & & \\
\hline & OS_7 & 0.880 & 0.774 & & \\
\hline & OS_9 & 0.817 & 0.667 & & \\
\hline & OS_10 & 0.909 & 0.826 & & \\
\hline & OS_11 & 0.835 & 0.697 & & \\
\hline & OS_12 & 0.904 & 0.817 & & \\
\hline \multirow{8}{*}{ 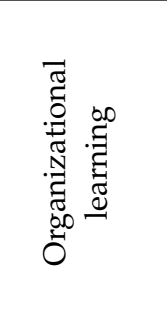 } & OL_2 & 0.791 & 0.626 & \multirow{8}{*}{0.837} & \multirow{8}{*}{0.771} \\
\hline & OL_3 & 0.892 & 0.796 & & \\
\hline & OL_5 & 0.849 & 0.721 & & \\
\hline & OL_6 & 0.923 & 0.852 & & \\
\hline & OL_7 & 0.898 & 0.806 & & \\
\hline & OL_8 & 0.873 & 0.762 & & \\
\hline & OL_9 & 0.906 & 0.821 & & \\
\hline & OL_10 & 0.884 & 0.781 & & \\
\hline \multirow{7}{*}{ 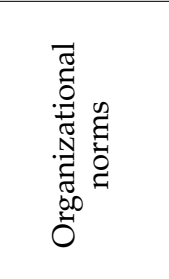 } & ON_1 & 0.906 & 0.821 & \multirow{7}{*}{0.809} & \multirow{7}{*}{0.760} \\
\hline & ON_2 & 0.784 & 0.615 & & \\
\hline & ON_3 & 0.844 & 0.712 & & \\
\hline & ON_4 & 0.909 & 0.826 & & \\
\hline & ON_6 & 0.763 & 0.582 & & \\
\hline & ON_7 & 0.978 & 0.956 & & \\
\hline & ON_10 & 0.899 & 0.808 & & \\
\hline \multirow{3}{*}{$\frac{1}{0} \frac{0}{0}$} & AD_1 & 0.896 & 0.803 & \multirow{3}{*}{0.904} & \multirow{3}{*}{0.856} \\
\hline & AD_2 & 0.985 & 0.970 & & \\
\hline & AD_3 & 0.891 & 0.794 & & \\
\hline \multirow{4}{*}{ 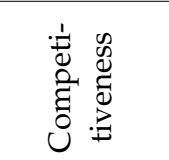 } & CN_1 & 0.870 & 0.757 & \multirow{4}{*}{0.835} & \multirow{4}{*}{0.802} \\
\hline & CN_2 & 0.937 & 0.878 & & \\
\hline & CN_3 & 0.867 & 0.752 & & \\
\hline & CN_4 & 0.906 & 0.821 & & \\
\hline
\end{tabular}

Here, $F L_{1}$ is the standardized factor loadings of measurement item $i, n$ is the number of items in a factor, and $M E_{1}$ is the measurement error of item $i . M E_{1}$ is crafted from: $\sum 1-f l_{1}^{2}$.

Table 2 indicates that all the indicators passed the threshold value of 0.07 [65]. Therefore, the study possessed a strong validity of the conceptual framework. The next assessment was to confirm the divergent or discriminant validity (DV) and to confirm the DV, squared correlations of all latent variables should be measured in a matrix and compared with their average variance extracted $[95,98]$. Average variance extracted (AVE) was crafted for satisfying the convergent validity and DV by using the following equation crafted by Hair [99]:

$$
\mathrm{AVE}=\frac{\sum \sum_{i=1}^{n} f l_{1}^{2}}{n}
$$

Here, $F L_{1}$ is the standardized factor loadings of measurement item $i, n$ is the number of items in a factor. Table 2 indicates that AVE for all the indicators is well secured with the accepted values of 0.5 [100]. The study used the Fornell-Larcker criterion for providing DV as portrayed in Table 3. The table shows that square root values are greater than the correlated values of all the associated indicators, which secured the DV as subsisted by Hair [99]. Additionally, Table 2 showed that CFI (comparative fit index) and TLI (TuckerLewis index) hold higher values than the accepted value 0.90, the RMSEA (root mean square error approximation) and SRMR (standardized root mean square residual) denoted 
the lower values than the threshold of 0.08 [65]. Therefore, the measurement model was confirmed as a substantially good fit.

Table 3. Fornell-Larcker criterion analysis for checking discriminant validity.

\begin{tabular}{cccccc}
\hline & $\begin{array}{c}\text { Organizational } \\
\text { Support }\end{array}$ & $\begin{array}{c}\text { Organizational } \\
\text { Learning }\end{array}$ & $\begin{array}{c}\text { Organizational } \\
\text { Norms }\end{array}$ & Adoption & $\begin{array}{c}\text { Competitive } \\
\text { Advantage }\end{array}$ \\
\hline $\begin{array}{c}\text { Organizational } \\
\text { Support }\end{array}$ & $\mathbf{0 . 8 7 0}$ & & & & \\
$\begin{array}{c}\text { Organizational } \\
\text { Learning }\end{array}$ & 0.790 & $\mathbf{0 . 8 7 8}$ & & & \\
$\begin{array}{c}\text { Organizational } \\
\text { Norms }\end{array}$ & 0.679 & 0.71 & $\mathbf{0 . 8 7 2}$ & & \\
$\quad$ Adoption & 0.574 & 0.671 & 0.703 & $\mathbf{0 . 9 2 5}$ & \\
Competitive & 0.503 & 0.432 & 0.568 & 0.592 & $\mathbf{0 . 8 9 6}$ \\
Advantage & & & & & \\
\hline
\end{tabular}

\subsubsection{Structural Model Representation}

After endorsing the reliability and validity of the measurement model, the next stage was to fit the measurement model to the structural model. The interconnection among the latent variables and their associated indicator was developed within the structural model, as shown by Wong [66]. He suggested that the common method bias test followed by bootstrapping (PLS-based multivariate bootstrapping) should be used for providing a clear and viable structural model. Bootstrapping is a multidimensional tactic that consents to observe the numerical connotation of various PLS-SEM outputs, for example, path coefficients, Cronbach's alpha, and $\mathrm{R}^{2}$ values. Bootstrapping procedures firstly indulge in the measurement of the mean and variance of all latent variables, and after that, actual mean and variance were compared with t-statistics. The above mechanisms, therefore, assist in identifying the T-value evaluation and ensure that the structural pathway approximation remains accurate [101]. A significant set of different observations (for example, 5000) were collected first from overall substitution samples to generate bootstrap sampling error and then provide the systemic direction estimated T-values. In PLS-SEM, bootstrapping has to be used for providing a consistent construct and outcomes (see Tables 4 and 5). As demonstrated earlier (Table A3 Appendix B), the study does not contain any issues of common method bias. Therefore, the study utilized two-tailed t-tests at a 5\% significance level (see Table 5). The factor loading of the entire set of variables (outer model) contains values more than 0.7 (see Figure 2). Therefore, it indicates the factor loadings hold the minimum established value as suggested by Hair et al. [102]. We used "SmartPLS-3" software to measure the factor loading of all the variables and "t-test" as portrayed in Table 4 (inner model) and Table 5 (outer model). Tables 4 and 5 indicated that the value is well above the accepted value of 1.96, which confirms there is significant interaction among all of the latent variables [71], and the model holds statistically viable values.

Table 6 signifies the prime outcomes of the study. Table 6 indicated the t-statistics (bootstrapping results) of hypotheses 1, 2, 3, and 4 accounted for 21.675, 9.374, 8.437, and 6.756 , respectively, which are well above the accepted value of 1.96. It indicates the model represents considerable measurement loading for the entire set of associated indicators [66]. The structured framework established a statistically viable and significant interaction that has also been found among all the indicators. Moreover, all the associated theories and hypotheses are legitimately reliable as tested by T-measurement estimation.

Table 4. Bootstrap results of the model (inner model).

\begin{tabular}{cc}
\hline & T-Statistics \\
\hline Adoption $\rightarrow$ Competitive advantage & 12.218 \\
Organizational support $\rightarrow$ Adoption & 5.756 \\
Organizational Learning $\rightarrow$ Adoption & 4.753 \\
Organizational Norms $\rightarrow$ Adoption & 4.136 \\
\hline
\end{tabular}


By considering the above viewpoint, the study concludes the final results as:

H1: Organizational learning is positively correlated with farmers of cooperatives to adopt EFT (accepted).

H2: Organizational support is positively correlated with farmers of cooperatives to adopt EFT (accepted).

H3: Organizational norms are positively correlated with farmers of cooperatives to adopt EFT (accepted).

H4: The adoption of EFT positively influences fostering the competitiveness of the farm (accepted).

Table 5. Bootstrap results of the model (outer model).

\begin{tabular}{|c|c|c|c|c|c|}
\hline Frame/Construct & Indicator & $\begin{array}{l}\text { Total Sample } \\
\text { Estimate }\end{array}$ & $\begin{array}{c}\text { Mean of } \\
\text { Subsample }\end{array}$ & $\begin{array}{c}\text { Standard } \\
\text { Error }\end{array}$ & t-Statistics \\
\hline \multirow{8}{*}{ 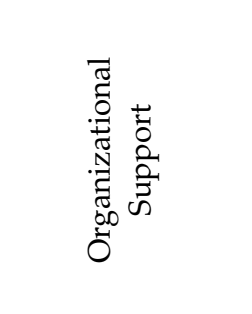 } & OS_1 & 0.261 & 0.261 & 0.0043 & 29.129 \\
\hline & OS_5 & 0.246 & 0.244 & 0.0093 & 27.142 \\
\hline & OS_6 & 0.279 & 0.271 & 0.0031 & 22.328 \\
\hline & OS_7 & 0.255 & 0.245 & 0.0071 & 26.491 \\
\hline & OS_9 & 0.319 & 0.309 & 0.0040 & 26.189 \\
\hline & OS_10 & 0.302 & 0.292 & 0.0091 & 21.186 \\
\hline & OS_11 & 0.294 & 0.291 & 0.0102 & 17.283 \\
\hline & OS_12 & 0.268 & 0.268 & 0.0089 & 16.367 \\
\hline \multirow{8}{*}{ 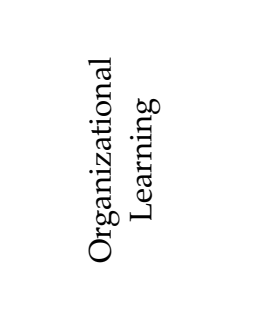 } & OL_2 & 0.298 & 0.278 & 0.0099 & 13.208 \\
\hline & OL_3 & 0.439 & 0.409 & 0.0102 & 11.043 \\
\hline & OL_5 & 0.398 & 0.308 & 0.0075 & 8.233 \\
\hline & OL_6 & 0.358 & 0.348 & 0.0092 & 14.344 \\
\hline & OL_7 & 0.281 & 0.261 & 0.0087 & 11.089 \\
\hline & OL_8 & 0.346 & 0.336 & 0.0076 & 6.233 \\
\hline & OL_9 & 0.286 & 0.271 & 0.0103 & 8.123 \\
\hline & OL_10 & 0.357 & 0.347 & 0.0091 & 12.509 \\
\hline \multirow{7}{*}{ 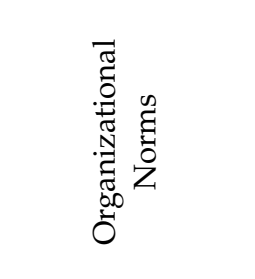 } & ON_1 & 0.213 & 0.203 & 0.0018 & 28.754 \\
\hline & ON_2 & 0.409 & 0.399 & 0.0094 & 26.302 \\
\hline & ON_3 & 0.246 & 0.246 & 0.0031 & 29.062 \\
\hline & ON_4 & 0.345 & 0.342 & 0.0043 & 22.489 \\
\hline & ON_6 & 0.249 & 0.249 & 0.0103 & 29.830 \\
\hline & ON_7 & 0.366 & 0.362 & 0.0101 & 22.302 \\
\hline & ON_10 & 0.476 & 0.401 & 0.0528 & 21.128 \\
\hline \multirow{3}{*}{$\frac{1}{\frac{1}{0}} .0$} & AD_1 & 0.234 & 0.234 & 0.0018 & 31.038 \\
\hline & AD_2 & 0.345 & 0.345 & 0.0071 & 23.602 \\
\hline & AD_3 & 0.166 & 0.166 & 0.0031 & 21.223 \\
\hline \multirow{4}{*}{ 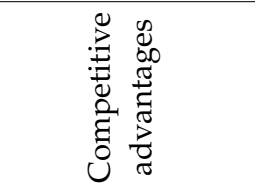 } & CN_1 & 0.419 & 0.403 & 0.0018 & 27.766 \\
\hline & CN_2 & 0.373 & 0.334 & 0.0071 & 29.402 \\
\hline & CN_3 & 0.289 & 0.289 & 0.0092 & 28.030 \\
\hline & CN_4 & 0.357 & 0.341 & 0.0091 & 31.089 \\
\hline
\end{tabular}


Table 6. Parameters of the structural model.

\begin{tabular}{ccccc}
\hline Hypothesis & Total Sample Estimate & Mean of Subsample & Standard Error & t-Statistics \\
\hline Organizational Support-adoption & 0.979 & 0.906 & 0.039 & 21.675 \\
Organizational learning-adoption & 0.714 & 0.691 & 0.066 & 9.374 \\
Organizational norms-adoption & 0.803 & 0.712 & 0.049 & 8.437 \\
Adoption-competitive advantage & 0.983 & 0.894 & 0.089 & 6.756 \\
\hline
\end{tabular}

\section{Discussion and Implication of the Study}

The effective adoption of EFT among the farmers can result in a step forward to green and sustainable farming planning, which is considered a prime dilemma of the modern world, especially for the growing economy as most of the framers possessed low awareness, skills, and technical know-how about EFT [103]. Fostering the influence of farmer's organizations or cooperatives might have a substantial impact on facilitating the smooth adoption transition [39]. As a result, the government of China has established several policy recommendations to uphold the importance of cooperative organization [104]. However, the understanding of the adoption of farmers mostly depends on distinctive factors and is likely complicated too. Especially, the growing economy like China, where personal relationship, support, and mutual understanding play a crucial role in profiling farmers' behavior to a great extent and, thus, it is expected the interaction of the farmers' cooperatives in the form of organizational support, organizational norms, and organizational learning might be profound [54]. Thus, based on extensive literature investigation, the study comprised 23 indicators that can foster three key variables (organizational supports, learning, and norms) and built a structural model that represents the interrelationship between the adoption of EFT. Moreover, the studies extended the model by measuring the effects of adoption in the form of a competitive advantage, which is the key innovation of the study. The conceptual model was then measured, structured, and statistically verified with the help of 292 farmers from 38 kiwifruit cooperative of Meixian County, China.

The study comprised substantial effects of organizational supports for maintaining smooth transition for adopting EFT, which is parallel with the results of Aubert et al. [105]. Parallel with the outcomes of Lee [106], the impacts of organizational learning within the Meixian kiwifruit farmers are also found relatively high. Though the interaction of organization norms for adopting EFT is significant, however, organization supports and learning possessed better influence than the organizational norms, which is quite different from the study of Lynne et al. [107] and Higgins et al. [108]. Overall the study comprised a staggering relationship among the key variables of organizational supports, organizational learning, and organizational norms. Interestingly, parallel with the existing research on farmers' adoption of environmentally friendly technology [109-111], the study also found a substantial impact of EFT for availing competitive advantage.

While, Yigezu et al. [112] found initial investment somehow hinders the adoption and scaling up of sustainable, eco-friendly technology among Syrian wheat and barley farmers. The studied farmers also provided greater emphasis on the initial investment as the factor loading of the variables regarding initial investment (OS_11) were found to be relatively high. Provision to credit and off-farm earnings can significantly reduce restrictions on flexibility and thereby increase access to appropriate technological, operational, and resource supplies $[113,114]$; the current study also traced a sufficient influence of credit/loan facilities assessed by the organizations (OS_5). As most of the environmentally friendly technologies in China are relatively new, that could be possible that the study found, as training facilities have substantial impacts on adoption $[115,116]$. Parallel with the results of Doss [117], the study comprised a substantial impact of farmer's experience (OL_6 and OL_7) on EFT adoption. Mwalupaso et al. [118] found strong associations and networks of the adoption of EFT and the concepts of cleaner production, which is quite similar to our findings. Organizational encouragement for maintaining cleaner production tactics and fostering social responsibility (ON_1) was found to be positive within the 
Meixian kiwifruit farmers. The study revealed that as the cooperative organization handles the short-term risk (as EFT might not produce an instant outcome), the farmers most likely are on the happier side to adopt EFT (ON_10), which reflects a similar finding to Liu [119]. As information-sharing facilities provided by cooperative organizations can foster the transitional effects among the farmers [120], the study found a positive interaction of information services has a larger influence among the studied farmers. Seemingly, being a part of the organization, farmers are often encouraged or somehow forced to maintain certain EFT interaction within the farms to maintain standard [121,122]; the study also found positive impacts of standardization relatively high (ON_3). It is quite obvious that as part of an organization, many farmers might have to face some distinctive problems (OS_6,OS_9, and OS_10) and some technical issues while if the organization is ready to solve them and facilitate better negotiation for adopting EFT (OS_12), the farmers are likely to adopt the EFT more confidently [13,54], which is similar to our findings.

\section{Conclusions}

The general issue of mutual EFT adopting tendencies among farmers has been of vital importance for the government and academia. Several studies have intended to explore the drivers and barriers which motivate or demotivate farmers for adopting EFT and the utilization of that technology within bigger dimensions. Research has predominantly focused on the advantages, mediating roles, and participatory roles of cooperatives and farmer's behavioral factors affecting the adoption of modern EFT at the farm level. Moreover, prior studies mostly focused on the organizational mechanism and the effects of participation in cooperatives. Whereas, how the cooperative organizations mechanize the smooth transition of EFT among the farmers and how organizational learning, supports, and norms assist the farmers to adopt EFT has remained unexplored. Therefore, the study utilized integrated approaches to substantially explore to what extent the organizational learning, organizational norms, and support foster the adoption and how the adoption of EFT fosters the smooth transition of capturing competitive advantage.

Though organizational participation on the basis of cooperative behavior has a long history, there is a lack of research triggering the interconnection among organizational supports, organizational norms, and organizational learning. Especially, evaluating the role of organizational supports, norms, and learning within the context of farmer's cooperatives is relatively rare. The study established a statistically viable model with the help of empirical data from 292 farmers of 38 kiwifruit cooperatives of Meixian County, Shaanxi, China. A conceptual model was proposed, structured, and secured robustness of the model by utilizing partial least square-based SEM. The study found a significantly positive relationship between organizational supports and adoption of EFT, organizational learning and adoption of EFT, and organizational norms and adoption of EFT. The study also found organizational support, learning, and norms possessed staggering effects to foster farmer's overall knowledge, impression and formulate a positive attitude towards EFT. Consistent with other studies, the study revealed that there is a positive interconnection between the adoption of EFT and the availing competitive advantages.

Our study comprised some distinct policy recommendations. A deeper assessment of the roles of cooperative societies in fostering the transmission of agricultural EFT will strengthen the status and implementation of policy initiatives, which is especially relevant for economies having vast, remote communities that have been characterized by small farms, such as China. The interrelationship between environmentally friendly technology and cooperative organizations in the studied regions was found substantial; especially, EFT adoption was traced within the post-harvesting mechanism with eventually helping farmers to avail better opportunity to boost their income. Kiwifruit farmers of Meixian put great emphasis on the positive effects of EFT for maintaining low production costs and economic benefits. Thus, the government should provide more attention to smoothening the financial access of the cooperatives. As the study found organizational norms within reactively weaker parts for fostering the adoption compared to other latent variables (supports and 
learning), multidisciplinary and systematic initiatives should be used as part of successful EFT promotion initiatives among kiwi farmers, with the emphasis on norms and values. Interestingly, the studied farmers also highlighted the better opportunity of distinctive market and demands of cleaner production facilities. Therefore, the policymakers and sectors should emphasize more to improve the awareness level of local people and consumers as well. In this regard, training facilities, advertisement, rewards, and better loan facilities should be available to maintain a smooth transition of EFT within the agriculture sectors.

The study possessed some limitations too. The first limitation is the study collected the data in a single wave. Thus, there is profound grounds to compare the impacts of the identified indicators into various regions and various time waves. Moreover, the scope and intensity of the use of certain technologies have not been quantified in our analysis, whereas overall technologies adopted by the farmers were taken into account. It will be interesting to evaluate any particular form of technology. The study utilized the structural equation modeling, which has some potential drawbacks as it usually deals the complex interactions and multivariate indicators are usually used for evaluation which demands extensive literature and theoretical support. Moreover, SEM has several aspects, while we utilized partial least square (PLS) based aspects of the SEM, thus if the outcome could compare with covariate based (CB) SEM, it will be very interesting. The proposed model of the study could be elaborated for future research. First, the interaction of organizational participation can be included to measure how organizational participation can profile the behavior of farmers. Secondly, the theory of planned behavior can be used to interact with the three main latent variables (organizational supports, learning, and norms). Another research direction could be how perceived values provided by the cooperative foster the adoption of EFT. Finally, whether the cooperative organization has any mediating role for availing new technology could be very interesting as well. Moreover, the study used a local data which only triggered the specific regions of China; it would be very interesting if the outcomes could be tested within various cultural circumstances.

Author Contributions: Conceptualization, H.W., and A.S.; methodology, H.W.; software, A.S.; validation, H.W., A.S., and L.Q.; formal analysis, A.S; investigation, H.W.; resources, H.W.; data curation, A.S.; writing-original draft preparation, A.S., and H.W.; writing-review and editing, H.W.; visualization, A.S.; supervision, L.Q.; project administration, L.Q.; funding acquisition, L.Q. All authors have read and agreed to the published version of the manuscript.

Funding: This research was funded by THE NATIONAL NATURAL SCIENCE FOUNDATION OF CHINA, grant number 7197030867" and "The APC was funded by THE NATIONAL NATURAL SCIENCE FOUNDATION OF CHINA (grant number 7197030867).

Data Availability Statement: Data will be supplied upon request to the corresponding author.

Acknowledgments: The Authors like to thank Md. Ashfikur Rahman for his outstanding inputs regarding the methodology and tools.

Conflicts of Interest: The authors declare no conflict of interest. 


\section{Appendix A.}

Table A1. Excerpt of the questionnaire used in the research.

\begin{tabular}{|c|c|c|c|c|c|c|c|}
\hline \multicolumn{3}{|c|}{ Questions (Related to the Constructs) } & \multirow{2}{*}{$\begin{array}{c}\text { Stronglydisagree } \\
1\end{array}$} & \multirow{2}{*}{$\begin{array}{c}\text { Disagree } \\
2\end{array}$} & \multirow{2}{*}{$\begin{array}{c}\text { Neutral } \\
3\end{array}$} & \multirow{2}{*}{$\begin{array}{c}\begin{array}{c}\text { Agree to } \\
\text { someextent }\end{array} \\
4\end{array}$} & \multirow{2}{*}{$\begin{array}{c}\text { Stronglyagree } \\
5\end{array}$} \\
\hline \multirow{8}{*}{ 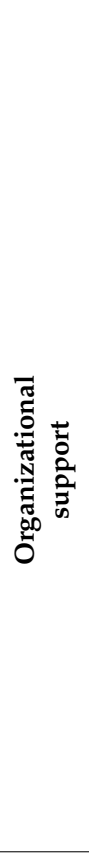 } & OS_1 & $\begin{array}{l}\text { Industry organizations care about my } \\
\text { production decision and opinion }\end{array}$ & & & & & \\
\hline & OS_5 & $\begin{array}{l}\text { Industry organization provides me } \\
\text { credits/loans facilities }\end{array}$ & 1 & 2 & 3 & 4 & 5 \\
\hline & OS_6 & $\begin{array}{l}\text { Industry organization provides me } \\
\text { technical support }\end{array}$ & 1 & 2 & 3 & 4 & 5 \\
\hline & OS_7 & $\begin{array}{l}\text { Industry organizations provide me with } \\
\text { information regarding market conditions, } \\
\text { availability of technological } \\
\text { advancements, information regarding } \\
\text { government policies }\end{array}$ & 1 & 2 & 3 & 4 & 5 \\
\hline & OS_9 & $\begin{array}{c}\text { Help is available from my organization } \\
\text { when I have any problem with initiating } \\
\text { new technologies }\end{array}$ & 1 & 2 & 3 & 4 & 5 \\
\hline & OS_10 & $\begin{array}{l}\text { My organization is willing to help me if I } \\
\text { need a special favor for adopting EFT }\end{array}$ & 1 & 2 & 3 & 4 & 5 \\
\hline & OS_11 & $\begin{array}{l}\text { I believe the initial investment handled by } \\
\text { cooperatives can affect the adoption } \\
\text { tactics }\end{array}$ & 1 & 2 & 3 & 4 & 5 \\
\hline & OS_12 & $\begin{array}{l}\text { If there is any problem with adopting the } \\
\text { EFT, the organization usually has the } \\
\text { option for negotiations }\end{array}$ & 1 & 2 & 3 & 4 & 5 \\
\hline \multirow{8}{*}{ 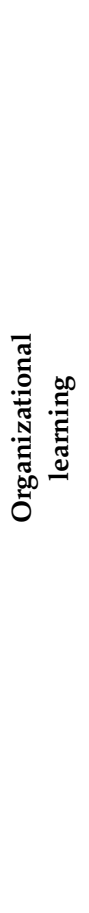 } & $\mathrm{OL} \_2$ & $\begin{array}{l}\text { I am satisfied with the training services of } \\
\text { the industrial organization }\end{array}$ & 1 & 2 & 3 & 4 & 5 \\
\hline & OL_3 & $\begin{array}{l}\text { I am satisfied with the information service } \\
\text { provided by my cooperative organization }\end{array}$ & 1 & 2 & 3 & 4 & 5 \\
\hline & OL_5 & $\begin{array}{l}\text { The cooperative organization has excellent } \\
\text { communication with farmers }\end{array}$ & 1 & 2 & 3 & 4 & 5 \\
\hline & OL_6 & $\begin{array}{l}\text { In participation in cooperative, all } \\
\text { members are sharing their experience and } \\
\text { tend to learn from each other }\end{array}$ & 1 & 2 & 3 & 4 & 5 \\
\hline & OL_7 & $\begin{array}{l}\text { I noticed the experience farmers in the } \\
\text { organization provide full support and } \\
\text { valuable input for adopting EFT }\end{array}$ & 1 & 2 & 3 & 4 & 5 \\
\hline & OL_8 & $\begin{array}{l}\text { My cooperative organization encourages } \\
\text { sharing information and knowledge } \\
\text { through openness }\end{array}$ & 1 & 2 & 3 & 4 & 5 \\
\hline & OL_9 & $\begin{array}{l}\text { My cooperative organization shared a } \\
\text { clear vision and objectives to use EFT } \\
\text { across the whole organization with the } \\
\text { active participation of members }\end{array}$ & 1 & 2 & 3 & 4 & 5 \\
\hline & OL_10 & $\begin{array}{l}\text { Performance measurement and reporting, } \\
\text { including individual and organizational } \\
\text { skills assessment, helped me to } \\
\text { understand the process and technical } \\
\text { know-how of EFT }\end{array}$ & 1 & 2 & 3 & 4 & 5 \\
\hline
\end{tabular}


Table A1. Cont.

\begin{tabular}{|c|c|c|c|c|c|c|c|}
\hline \multicolumn{3}{|c|}{ Questions (Related to the Constructs) } & \multirow{2}{*}{$\begin{array}{c}\text { Stronglydisagree } \\
1\end{array}$} & \multirow{2}{*}{$\begin{array}{c}\text { Disagree } \\
2 \\
2\end{array}$} & \multirow{2}{*}{$\begin{array}{c}\text { Neutral } \\
3\end{array}$} & \multirow{2}{*}{$\begin{array}{c}\begin{array}{c}\text { Agree to } \\
\text { someextent }\end{array} \\
\\
4\end{array}$} & \multirow{2}{*}{$\begin{array}{c}\text { Stronglyagree } \\
5 \\
5\end{array}$} \\
\hline \multirow{7}{*}{ 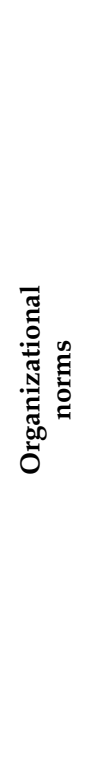 } & ON_1 & $\begin{array}{c}\text { Organizations encourage me to adopt the } \\
\text { EFT to uphold the stand towards cleaner } \\
\text { production tactics and fostering social } \\
\text { responsibility }\end{array}$ & & & & & \\
\hline & ON_2 & $\begin{array}{l}\text { Organizations always guide me to } \\
\text { maintain governmental regulations and } \\
\text { safety standard }\end{array}$ & 1 & 2 & 3 & 4 & 5 \\
\hline & ON_3 & $\begin{array}{l}\text { The organization always force me to } \\
\text { maintain standardization requirements }\end{array}$ & 1 & 2 & 3 & 4 & 5 \\
\hline & ON_4 & $\begin{array}{l}\text { I believe the standard requirement set by } \\
\text { the organization can be met by adopting } \\
\text { EFT }\end{array}$ & 1 & 2 & 3 & 4 & 5 \\
\hline & ON_6 & $\begin{array}{c}\text { I think the other farmers will follow } \\
\text { standard production as required by the } \\
\text { organizations }\end{array}$ & 1 & 2 & 3 & 4 & 5 \\
\hline & ON_7 & $\begin{array}{l}\text { If I do the violation of regulations and } \\
\text { used harmful materials, I will be } \\
\text { discovered by the supervisors }\end{array}$ & 1 & 2 & 3 & 4 & 5 \\
\hline & ON_10 & $\begin{array}{l}\text { Organizations help me to handle the short } \\
\text { term risk }\end{array}$ & 1 & 2 & 3 & 4 & 5 \\
\hline \multirow{3}{*}{ 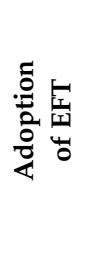 } & AD_1 & $\begin{array}{c}\text { My knowledge level for EFT has been } \\
\text { increased by participation in a cooperative } \\
\text { organization }\end{array}$ & 1 & 2 & 3 & 4 & 5 \\
\hline & AD_2 & $\begin{array}{c}\text { My impression regarding EFT has } \\
\text { improved }\end{array}$ & 1 & 2 & 3 & 4 & 5 \\
\hline & AD_3 & $\begin{array}{c}\text { Now I have a more positive attitude } \\
\text { towards EFT }\end{array}$ & 1 & 2 & 3 & 4 & 5 \\
\hline \multirow{4}{*}{ 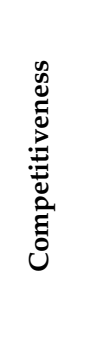 } & CN_1 & $\begin{array}{l}\text { EFT helps me to reduce the overall } \\
\text { production cost by reducing } \\
\text { input/resource waste }\end{array}$ & 1 & 2 & 3 & 4 & 5 \\
\hline & CN_2 & $\begin{array}{c}\text { EFT helps me to maintain the } \\
\text { organizational standard and product } \\
\text { quality }\end{array}$ & 1 & 2 & 3 & 4 & 5 \\
\hline & CN_3 & $\begin{array}{l}\text { EFT helps me to facilitate better prices } \\
\text { compared to conventional tactics }\end{array}$ & 1 & 2 & 3 & 4 & 5 \\
\hline & CN_4 & EFT helps me with production flexibility & 1 & 2 & 3 & 4 & 5 \\
\hline
\end{tabular}

\section{Appendix B.}

Appendix B.1. Common Method Bias Test

Appendix B.1.1. Exploratory Factor Analysis

According to Mumtaz and Parahoo [123], for measuring inner precisions and Harman's single factor test, exploratory factor analysis (EFA) could be useful to measure a single measurement of the indicators for the rest of the mechanisms.

Table A2. Exploratory factor analysis.

\begin{tabular}{ccc}
\hline $\begin{array}{c}\text { Kaiser-Meyer-Olkin Measure of Sampling } \\
\text { Adequacy }\end{array}$ & & $\mathbf{0 . 6 9 4}$ \\
\hline \multirow{3}{*}{ Bartlett's test of sphericity } & Approx chi-square & 1019.341 \\
\cline { 2 - 3 } & Df & 25 \\
\cline { 2 - 3 } & Sig. & 0.03 \\
\hline
\end{tabular}


From Table A2, it could be observed that the Kaiser-Meyer-Olkin (KMO) measure of the indicators was found as 0.797 , which denotes more than the required minimum values of $0.6[124,125]$. Bartlett's test of sphericity of significance $(p=0.03)$ implies that the research could have been perceived by a credible measurement model with statistical importance of $p<0.05$ as suggested by Lindell and Whitney [124]. The preliminary report (Table A4) also implies that the indicators have Bartlett's sphericity $\left(\chi^{2}\right)$ score (1019.341), with a 27.56 percent degree of freedom and significance level of 0.030 .

\section{Appendix B.1.2. Harman's Single-Factor Test}

Within the context of the study, we applied "Harman's single-factor test" as compiled by Podsakoff et al. [126] and Tehseen et al. [94]. In this research, the principal component analysis (PCA) and unrevealed correlation matrix were employed with the entire latent construct included in this research to evaluate if a single factor arises or a single factor accounted for more than $60 \%$ of the covariation. The measurements revealed that the overall variance accounted for $62.676 \%$ of the four factors of 12 components, whether the first indicators hold with $49.028 \%$ variance within the dataset. Overall interpretation of Table A3 shows that the dataset does not contain any single factor bias issues, and the values of the first factors also did not lead to the most variance. While this investigation did not find a problem of common method bias, the dataset is therefore valid for further evaluation.

Table A3. Harman's single factor test.

\begin{tabular}{ccccccc}
\hline \multirow{2}{*}{ Component } & \multicolumn{3}{c}{ Initial Eigenvalues } & \multicolumn{2}{c}{ Extraction Sums of Squared Loadings } \\
\cline { 2 - 6 } & Total & $\begin{array}{c}\text { \% of } \\
\text { Variance }\end{array}$ & Cumulative $\%$ & Total & $\begin{array}{c}\text { \% of } \\
\text { Variance }\end{array}$ & Cumulative \% \\
\hline 1 & 14.866 & 49.028 & 49.028 & 14.866 & 49.028 & 59.028 \\
\hline 2 & 1.589 & 5.451 & 54.479 & 1.589 & 5.451 & 54.479 \\
\hline 3 & 1.468 & 4.576 & 59.055 & 1.468 & 4.576 & 62.676 \\
\hline 4 & 1.085 & 3.621 & 62.676 & 1.085 & 3.621 & \\
\hline 5 & 0.986 & 3.416 & 66.092 & & & \\
\hline 6 & 0.897 & 3.073 & 69.165 & & & \\
\hline 7 & 0.765 & 2.518 & 71.683 & & & \\
\hline 8 & 0.629 & 2.142 & 73.825 & & & \\
\hline 9 & 0.576 & 1.956 & 75.781 & & & \\
\hline 10 & 0.546 & 1.864 & 77.645 & & & \\
\hline 11 & 0.536 & 1.871 & 79.516 & & & \\
\hline 12 & 0.523 & 1.787 & 81.303 & & & \\
\hline
\end{tabular}

\section{References}

1. FAO Global Agriculture Towards 2050. High Level Expert Forum-How to Feed the World in 2050. 2009. Available online: http:/ / www.fao.org/wsfs/forum2050/wsfs-forum/en/ (accessed on 27 January 2021).

2. Grafton, R.Q.; Daugbjerg, C.; Qureshi, M.E. Towards food security by 2050. Food Secur. 2015, 7, 179-183. [CrossRef]

3. Petridis, N.E.; Digkas, G.; Anastasakis, L. Factors affecting innovation and imitation of ICT in the agrifood sector. Ann. Oper. Res. 2020, 294, 501-514. [CrossRef]

4. Fagerberg, J. Technology, Growth and Competitiveness; Edward Elgar Publishing: Cheltenham, UK, 2002.

5. Corallo, A.; Latino, M.E.; Menegoli, M.; Striani, F. What factors impact on technological traceability systems diffusion in the agrifood industry? An Italian survey. J. Rural. Stud. 2020, 75, 30-47. [CrossRef]

6. Aceleanu, M.I. Sustainability and Competitiveness of Romanian Farms through Organic Agriculture. Sustainability $2016,8,245$. [CrossRef]

7. Ortmann, G.F. Promoting the Competitiveness of South African Agriculture in a Dynamic Economic and Political Environment. Agrekon 2005, 44, 286-320. [CrossRef]

8. Baig, M.B.; Shahid, S.A.; Straquadine, G.S. Making rainfed agriculture sustainable through environmental friendly technologies in Pakistan: A review. Int. Soil Water Conserv. Res. 2013, 1, 36-52. [CrossRef] 
9. Boz, I. Effects of environmentally friendly agricultural land protection programs: Evidence from the Lake Seyfe area of Turkey. J. Integr. Agric. 2016, 15, 1903-1914. [CrossRef]

10. Shrivastava, P. Environmental technologies and competitive advantage. Strat. Manag. J. 1995, 16, 183-200. [CrossRef]

11. Yeoshua, S.B. Environmentally Friendly Technologies for Agricultural Produce Quality; CRC Press: Boca Raton, FL, USA, 2005; ISBN 0-203-50036-9.

12. Kołecka, K.; Gajewska, M.; Obarska-Pempkowiak, H.; Rohde, D. Integrated dewatering and stabilization system as an environmentally friendly technology in sewage sludge management in Poland. Ecol. Eng. 2017, 98, 346-353. [CrossRef]

13. Zhang, S.; Sun, Z.; Ma, W.; Valentinov, V. The effect of cooperative membership on agricultural technology adoption in Sichuan, China. China Econ. Rev. 2020, 62, 101334. [CrossRef]

14. Adnan, N.; Nordin, S.M.; Bahruddin, M.A.; Tareq, A.H. A state-of-the-art review on facilitating sustainable agriculture through green fertilizer technology adoption: Assessing farmers behavior. Trends Food Sci. Technol. 2019, 86, 439-452. [CrossRef]

15. Mondal, P.; Basu, M. Adoption of precision agriculture technologies in India and in some developing countries: Scope, present status and strategies. Prog. Nat. Sci. 2009, 19, 659-666. [CrossRef]

16. Omara, H.; Odongo, W.; Kule, E.K. Adoption of environmentally friendly agricultural technologies among smallholder farmers: The case of rocket barn technology in flue-cured tobacco curing in Uganda. Land Degrad. Dev. 2021, 32, 965-974. [CrossRef]

17. Rodriguez, J.M.; Molnar, J.J.; Fazio, R.A.; Sydnor, E.; Lowe, M.J. Barriers to adoption of sustainable agriculture practices: Change agent perspectives. Renew. Agric. Food Syst. 2008, 24, 60-71. [CrossRef]

18. Luo, L.; Qin, L.; Wang, Y.; Wang, Q. Environmentally-friendly agricultural practices and their acceptance by smallholder farmers in China-A case study in Xinxiang County, Henan Province. Sci. Total. Environ. 2016, 571, 737-743. [CrossRef] [PubMed]

19. Wreford, A.; Ignaciuk, A.; Gruère, G. Overcoming barriers to the adoption of climate-friendly practices in agriculture. In $O E C D$ Food, Agriculture and Fisheries Papers; OECD Publishing: Paris, France, 2017.

20. Gibbs, D. Ecological modernisation, regional economic development and regional development agencies. Geoforum 2000, 31, 9-19. [CrossRef]

21. Bingen, J.; Serrano, A.; Howard, J. Linking farmers to markets: Different approaches to human capital development. Food Policy 2003, 28, 405-419. [CrossRef]

22. Zanello, G.; Srinivasan, C.S.; Shankar, B. Transaction Costs, Information Technologies, and the Choice of Marketplace among Farmers in Northern Ghana. J. Dev. Stud. 2014, 50, 1226-1239. [CrossRef]

23. Courtois, P.; Subervie, J. Farmer Bargaining Power and Market Information Services. Am. J. Agric. Econ. 2015, 97, 953-977. [CrossRef]

24. Seebens, H.; Sauer, J. Bargaining power and efficiency-rural households in Ethiopia. J. Int. Dev. 2007, 19, 895-918. [CrossRef]

25. Fischer, E.; Qaim, M. Linking Smallholders to Markets: Determinants and Impacts of Farmer Collective Action in Kenya. World Dev. 2012, 40, 1255-1268. [CrossRef]

26. Ortmann, G.F.; King, R.P. Agricultural Cooperatives I: History, Theory and Problems. Agrekon 2007, 46, 18-46. [CrossRef]

27. Harris, A.; Stefanson, B.; Fulton, M.E. New Generation Cooperatives and Cooperative Theory. J. Coop. 1996, 11, 15-28.

28. Prychitko, D.L.; Vanek, J. Producer Cooperatives and Labor-Managed Systems; Edward Elgar Publishing: Cheltenham, UK, 1996.

29. Albæk, S.; Schultz, C. On the relative advantage of cooperatives. Econ. Lett. 1998, 59, 397-401. [CrossRef]

30. Jepson, W. Producing a Modern Agricultural Frontier: Firms and Cooperatives in Eastern Mato Grosso, Brazil. Econ. Geogr. 2009, 82, 289-316. [CrossRef]

31. Birchall, J. Rediscovering the Cooperative Advantage-Poverty Reduction through Self-Help; International Labour Organisation; Cooperative Branch International Labour Office: Geneva, Switzerland, 2003; ISBN 92-2-113603-5.

32. Franks, J.; Mc Gloin, A. Environmental co-operatives as instruments for delivering across-farm environmental and rural policy objectives: Lessons for the UK. J. Rural. Stud. 2007, 23, 472-489. [CrossRef]

33. Cristobal-Fransi, E.; Montegut-Salla, Y.; Ferrer-Rosell, B.; Daries, N. Rural cooperatives in the digital age: An analysis of the Internet presence and degree of maturity of agri-food cooperatives' e-commerce. J. Rural. Stud. 2020, 74, 55-66. [CrossRef]

34. Mazzarol, T.; Limnios, E.M.; Reboud, S. Co-operatives as a strategic network of small firms: Case studies from Australian and French co-operatives. J. Coop. Organ. Manag. 2013, 1, 27-40. [CrossRef]

35. Attwood, D.M.; Baviskar, B.S. Why Do Some Co-Operatives Work but Not Others? A Comparative Analysis of Sugar CoOperatives in India. Econ. Political Wkly. 1987, 22, A38-A56.

36. Pascucci, S.; Gardebroek, C.; Dries, L. Some like to join, others to deliver: An econometric analysis of farmers' relationships with agricultural co-operatives. Eur. Rev. Agric. Econ. 2011, 39, 51-74. [CrossRef]

37. Nilsson, J. Governance costs and the problems of large traditional co-operatives. Outlook Agric. 2018, 47, 87-92. [CrossRef]

38. Luo, J.; Han, H.; Jia, F.; Dong, H. Agricultural Co-operatives in the western world: A bibliometric analysis. J. Clean. Prod. 2020, 273, 122945. [CrossRef]

39. Abebaw, D.; Haile, M.G. The impact of cooperatives on agricultural technology adoption: Empirical evidence from Ethiopia. Food Policy 2013, 38, 82-91. [CrossRef]

40. Cafer, A.M.; Rikoon, J.S. Adoption of new technologies by smallholder farmers: The contributions of extension, research institutes, cooperatives, and access to cash for improving tef production in Ethiopia. Agric. Hum. Values 2018, 35, 685-699. [CrossRef] 
41. Abnousi, V.K.; Karantemiris, K.; Doulis, A.G. Agricultural Cooperatives and Acceptance of Technological Innovation. In Proceedings of the Operational Research in Agriculture and Tourism; Krassadaki, E., Baourakis, G., Zopounidis, C., Matsatsinis, N., Eds.; Springer International Publishing: Cham, Switzerland, 2020; pp. 1-25.

42. Kolade, O.; Harpham, T. Impact of cooperative membership on farmers' uptake of technological innovations in Southwest Nigeria. Dev. Stud. Res. 2014, 1, 340-353. [CrossRef]

43. Wang, Y.-N.; Jin, L.; Mao, H. Farmer Cooperatives' Intention to Adopt Agricultural Information Technology—Mediating Effects of Attitude. Inf. Syst. Front. 2019, 21, 565-580. [CrossRef]

44. Mugisha, J.; Ajer, B.; Elepu, G. Contribution of Uganda Cooperative Alliance to Farmers' Adoption of Improved Agricultural Technologies. J. Agric. Soc. Sci. 2012, 8, 1-9.

45. Kehinde, A.; Adeyemo, R.; Oke, J.T.O.; Ogunleye, A.S. Effects of Access to Credit and Membership in Farmers' Cooperatives on Improved Technologies Adoption Categories in Cocoa-Based Farming Systems of Southwestern Nigeria. IJCS 2018, 7, 22-29. [CrossRef]

46. Gong, T.; Battese, G.E.; Villano, R.A. Family farms plus cooperatives in China: Technical efficiency in crop production. J. Asian Econ. 2019, 64, 101129. [CrossRef]

47. Nwankwo, U.M.; Peters, K.J.; Bokelmann, W. Can Cooperative Membership and Participation Affect Adoption Decisions? Issues for Sustainable Biotechnology Dissemination. 2009. Available online: http://www.agbioforum.missouri.edu/v12n34/v12n34a1 8-nwankwo.htm (accessed on 27 January 2021).

48. Ma, W.; Abdulai, A. IPM Adoption, Cooperative Membership and Farm Economic Performance: Insight from Apple Farmers in China. China Agric. Econ. Rev. 2019, 11, 218-236. [CrossRef]

49. Wossen, T.; Abdoulaye, T.; Alene, A.; Haile, M.G.; Feleke, S.; Olanrewaju, A.; Manyong, V. Impacts of extension access and cooperative membership on technology adoption and household welfare. J. Rural. Stud. 2017, 54, 223-233. [CrossRef]

50. Bernard, T.; Spielman, D.J. Reaching the rural poor through rural producer organizations? A study of agricultural marketing cooperatives in Ethiopia. Food Policy 2009, 34, 60-69. [CrossRef]

51. Iliopoulos, C. Public policy support for agricultural cooperatives: An organizational economics approach. Ann. Public Coop. Econ. 2013, 84, 241-252. [CrossRef]

52. Lafleur, M.; Burtak, S. Organizational Learning in Cooperatives: Way to Success. Econ. Manag. Mark. (AC-EMM) 2018, 45, 47-56.

53. Verhofstadt, E.; Maertens, M. Smallholder cooperatives and agricultural performance in Rwanda: Do organizational differences matter? Agric. Econ. 2014, 45, 39-52. [CrossRef]

54. Xu, G.; Sarkar, A.; Qian, L. Does organizational participation affect farmers' behavior in adopting the joint mechanism of pest and disease control? A study of Meixian County, Shaanxi Province. Pest Manag. Sci. 2021, 77, 1428-1443. [CrossRef] [PubMed]

55. Cropp, R.; Ingalsbe, G. Structure and Scope of Agricultural Cooperatives. Coop. Agric. 1989, 35-67. [CrossRef]

56. Hellin, J.; Lundy, M.; Meijer, M. Farmer organization, collective action and market access in Meso-America. Food Policy 2009, 34, 16-22. [CrossRef]

57. Oliver, N. An Examination of Organizational Commitment in Six Workers' Cooperatives in Scotland. Hum. Relat. 1984, 37, 29-45. [CrossRef]

58. Wittenbaum, G.M.; Hollingshead, A.B.; Botero, I.C. From cooperative to motivated information sharing in groups: Moving beyond the hidden profile paradigm. Commun. Monogr. 2004, 71, 286-310. [CrossRef]

59. Barton, D.G. What is Cooperative 2. Principles. Cooperatives in Agriculture/Edited by David Cobia-Englewood Cliff; Prentice Hall: Upper Saddle River, NJ, USA, 1989.

60. Helmberger, P.; Hoos, S. Cooperative Enterprise and Organization Theory. J. Farm Econ. 1962, 44, 275. [CrossRef]

61. Hogeland, J.A. The Economic Culture of U.S. Agricultural Cooperatives. Cult. Agric. 2006, 28, 67-79. [CrossRef]

62. Al Idrus, S.; Ahmar, A.S.; Abdussakir, A. Contribution of Organizational Learning and Market Orientation on Business Unit Performance Mediated by Job Satisfaction at Dairy Cattle Milk Cooperatives in East Java, Indonesia. J. Rev. Glob. Econ. 2018, 7, 207-216. [CrossRef]

63. Levay, C. Agricultural co-operative theory: A review*. J. Agric. Econ. 1983, 34, 1-44. [CrossRef]

64. Allaire, Y.; Firsirotu, M.E. Theories of Organizational Culture. Organ. Stud. 1984, 5, 193-226. [CrossRef]

65. Hair, J.F.; Ringle, C.M.; Sarstedt, M. Partial Least Squares Structural Equation Modeling: Rigorous Applications, Better Results and Higher Acceptance. Long Range Plan. 2013, 46, 1-12. [CrossRef]

66. Wong, K.K.-K. Partial Least Squares Structural Equation Modeling (PLS-SEM) Techniques Using SmartPLS. Mark. Bull. 2013, 24, $1-32$.

67. May, D.; Arancibia, S.; Behrendt, K.; Adams, J. Preventing young farmers from leaving the farm: Investigating the effectiveness of the young farmer payment using a behavioural approach. Land Use Policy 2019, 82, 317-327. [CrossRef]

68. Wang, J.; Tao, J.; Yang, C.; Chu, M.; Lam, H. A general framework incorporating knowledge, risk perception and practices to eliminate pesticide residues in food: A Structural Equation Modelling analysis based on survey data of 986 Chinese farmers. Food Control. 2017, 80, 143-150. [CrossRef]

69. Akter, S.; Wamba, S.F.; Dewan, S. Why PLS-SEM is suitable for complex modelling? An empirical illustration in big data analytics quality. Prod. Plan. Control. 2017, 28, 1011-1021. [CrossRef]

70. Sarkar, A.; Qian, L.; Peau, A.K. Structural equation modeling for three aspects of green business practices: A case study of Bangladeshi RMG's industry. Environ. Sci. Pollut. Res. 2020, 27, 1-19. [CrossRef] [PubMed] 
71. Mutyasira, V.; Hoag, D.; Pendell, D. The adoption of sustainable agricultural practices by smallholder farmers in Ethiopian highlands: An integrative approach. Cogent Food Agric. 2018, 4, 1552439. [CrossRef]

72. Ferraz, L.Z.T.; Rezende, A.J.; de Lima, J.P.R.; Todeva, E. Perception of Value Co-Creation Actions in Agricultural Cooperatives. BAR-Braz. Adm. Rev. 2018, 15. [CrossRef]

73. Guzmán, C.; Santos, F.J.; Barroso, M.D.L.O. Analysing the links between cooperative principles, entrepreneurial orientation and performance. Small Bus. Econ. 2019, 55, 1075-1089. [CrossRef]

74. Al Idrus, S.; Ahmar, A.S.; Abdussakir; Wu, Y.-C.J. The effect of organizational learning on market orientation moderated by job satisfaction. Cogent Bus. Manag. 2018, 5, 1475048. [CrossRef]

75. Le Dang, H.; Li, E.; Nuberg, I.; Bruwer, J. Understanding farmers' adaptation intention to climate change: A structural equation modelling study in the Mekong Delta, Vietnam. Environ. Sci. Policy 2014, 41, 11-22. [CrossRef]

76. Rhoades, L.; Eisenberger, R. Perceived organizational support: A review of the literature. J. Appl. Psychol. 2002, 87, 698-714. [CrossRef]

77. Colbert, A.E.; Bono, J.E.; Purvanova, R.K. Flourishing via Workplace Relationships: Moving Beyond Instrumental Support. Acad. Manag. J. 2016, 59, 1199-1223. [CrossRef]

78. Mathieu, M.; Eschleman, K.J.; Cheng, D. Meta-analytic and multiwave comparison of emotional support and instrumental support in the workplace. J. Occup. Health Psychol. 2019, 24, 387-409. [CrossRef]

79. Frambach, R.T.; Schillewaert, N. Organizational innovation adoption: A multi-level framework of determinants and opportunities for future research. J. Bus. Res. 2002, 55, 163-176. [CrossRef]

80. Jiménez-Jiménez, D.; Sanz-Valle, R. Innovation, organizational learning, and performance. J. Bus. Res. 2011, 64, 408-417. [CrossRef]

81. Deji, O.F. Membership of Co-Operative Societies and Adoption Behavior of Women Farmers: Implication for Rural Development. J. Soc. Sci. 2005, 10, 145-147. [CrossRef]

82. Akyüz, N.C.; Theuvsen, L. The Impact of Behavioral Drivers on Adoption of Sustainable Agricultural Practices: The Case of Organic Farming in Turkey. Sustainability 2020, 12, 6875. [CrossRef]

83. Mittal, V.K.; Sangwan, K.S. Development of a structural model of environmentally conscious manufacturing drivers. J. Manuf. Technol. Manag. 2014, 25, 1195-1208. [CrossRef]

84. Song, J. Kiwifruit's Hometown to Hold World Conference. 2017. Available online: chinadaily.com.cn (accessed on 17 January 2021).

85. Liu, Z. Experiment Station-Based Sci-Tech Innovation, Demonstration and Extension for Shaanxi Kiwifruit Industry. In Proceedings of the Scripta Horticulturae 20: Global Kiwifruit Industrial Development Conference; Scripta Horticulturae: Pastoriestraat, Belgium, 2019; pp. 1-200.

86. Xu, Y.; Hendrikse, G.W.J.; Guo, H.; Liang, Q. Characterizing Cooperatives in China. In Management and Governance of Networks: Franchising, Cooperatives, and Strategic Alliances; Hendrikse, G.W.J., Cliquet, G., Ehrmann, T., Windsperger, J., Eds.; Contributions to Management Science; Springer International Publishing: Cham, Switzerland, 2017; pp. 213-231. ISBN 978-3-319-57276-5.

87. Afthanorhan, W. Hierarchical Component Using Reflective-Formative Measurement Model in Partial Least Square Structural Equation Modeling (Pls-Sem). Int. J. Math. 2014, 2, 33-49.

88. Hoyle, R.H. The structural equation modeling approach: Basic concepts and fundamental issues. In Structural Equation Modeling: Concepts, Issues, and Applications; Sage Publications, Inc.: Thousand Oaks, CA, USA, 1995; pp. 1-15. ISBN 978-0-8039-5317-8.

89. Marcoulides, G.A.; Saunders, C. Editor's Comments: PLS: A Silver Bullet? MIS Q. 2006, 30, iii-ix. [CrossRef]

90. Asfaw, S.; Shiferaw, B.; Simtowe, F.; Lipper, L. Impact of modern agricultural technologies on smallholder welfare: Evidence from Tanzania and Ethiopia. Food Policy 2012, 37, 283-295. [CrossRef]

91. Barone, M.; DeCarlo, T. Emerging Forms of Competitive Advantage: Implications for Agricultural Producers. MATRIC Research Papers. 2003. Available online: https:/ / lib.dr.iastate.edu/matric_researchpapers / 8 (accessed on 17 January 2021).

92. Gandhi, V.P. Technology, Cost Reduction, and Returns in Agriculture: A Study of Wheat and Rice in Punjab. Vikalpa 1997, 22, 35-48. [CrossRef]

93. Requier-Desjardins, D.; Boucher, F.; Cerdan, C. Globalization, competitive advantages and the evolution of production systems: Rural food processing and localized agri-food systems in Latin-American countries. Entrep. Reg. Dev. 2003, 15, 49-67. [CrossRef]

94. Tehseen, S.; Sajilan, S.; Gadar, K.; Ramayah, T. Assessing Cultural Orientation as a Reflective-Formative Second Order Construct-a Recent PLS-SEM Approach. Rev. Integr. Bus. Econ. Res. 2017, 6, 38.

95. Munim, Z.H.; Noor, T. Young people's perceived service quality and environmental performance of hybrid electric bus service. Travel Behav. Soc. 2020, 20, 133-143. [CrossRef]

96. Anderson, J.C.; Gerbing, D.W. Structural equation modeling in practice: A review and recommended two-step approach. Psychol. Bull. 1988, 103, 411-423. [CrossRef]

97. Hair, J.F.; Black, W.C.; Babin, B.J.; Anderson, R.E.; Tatham, R.L. Multivariate Data Analysis; Prentice Hall: Upper Saddle River, NJ, USA, 1998; Volume 5.

98. Fornell, C.; Larcker, D.F. Evaluating Structural Equation Models with Unobservable Variables and Measurement Error. J. Mark. Res. 1981, 18, 39-50. [CrossRef]

99. Hair, J.F. Multivariate Data Analysis with Readings; Prentice Hall: Upper Saddle River, NJ, USA, 1995.

100. Bagozzi, R.P.; Yi, Y. On the evaluation of structural equation models. J. Acad. Mark. Sci. 1988, 16, 74-94. [CrossRef] 
101. Streukens, S.; Leroi-Werelds, S. Bootstrapping and PLS-SEM: A step-by-step guide to get more out of your bootstrap results. Eur. Manag. J. 2016, 34, 618-632. [CrossRef]

102. Hair, J.F.; Sarstedt, M.; Pieper, T.M.; Ringle, C.M. The Use of Partial Least Squares Structural Equation Modeling in Strategic Management Research: A Review of Past Practices and Recommendations for Future Applications. Long Range Plan. 2012, 45, 320-340. [CrossRef]

103. Isik, M. Incentives for Technology Adoption under Environmental Policy Uncertainty: Implications for Green Payment Programs. Environ. Resour. Econ. 2004, 27, 247-263. [CrossRef]

104. Loubere, N.; Zhang, H.X. Co-operative financial institutions and local development in China. J. Coop. Organ. Manag. 2015, 3, 32-39. [CrossRef]

105. Aubert, B.A.; Schroeder, A.; Grimaudo, J. IT as enabler of sustainable farming: An empirical analysis of farmers' adoption decision of precision agriculture technology. Decis. Support Syst. 2012, 54, 510-520. [CrossRef]

106. Lee, D.R. Agricultural Sustainability and Technology Adoption: Issues and Policies for Developing Countries. Am. J. Agric. Econ. 2005, 87, 1325-1334. [CrossRef]

107. Lynne, G.D.; Casey, C.F.; Hodges, A.; Rahmani, M. Conservation technology adoption decisions and the theory of planned behavior. J. Econ. Psychol. 1995, 16, 581-598. [CrossRef]

108. Higgins, V.; Bryant, M.; Howell, A.; Battersby, J. Ordering adoption: Materiality, knowledge and farmer engagement with precision agriculture technologies. J. Rural Stud. 2017, 55, 193-202. [CrossRef]

109. Mahfudz, M.; Saleh, S.; Antara, M.; Anshary, A.; Bachri, S.; Made, U.; Hasanah, U.; Rauf, R.A. Adoption and Advantages of Eco-Friendly Technology Application at the Shallot Farming System in Indonesia. Agron. Res. 2019, 17, $1679-1687$.

110. Ogunlana, E.A. The technology adoption behavior of women farmers: The case of alley farming in Nigeria. Renew. Agric. Food Syst. 2004, 19, 57-65. [CrossRef]

111. Tal, A. Making Conventional Agriculture Environmentally Friendly: Moving beyond the Glorification of Organic Agriculture and the Demonization of Conventional Agriculture. Sustainability 2018, 10, 1078. [CrossRef]

112. Yigezu, Y.A.; Mugera, A.; El-Shater, T.; Aw-Hassan, A.; Piggin, C.; Haddad, A.; Khalil, Y.; Loss, S. Enhancing adoption of agricultural technologies requiring high initial investment among smallholders. Technol. Forecast. Soc. Chang. 2018, 134, 199-206. [CrossRef]

113. Doss, C.R. Analyzing technology adoption using microstudies: Limitations, challenges, and opportunities for improvement. Agric. Econ. 2006, 34, 207-219. [CrossRef]

114. Migliorelli, M.; Dessertine, P. Time for new financing instruments? A market-oriented framework to finance environmentally friendly practices in EU agriculture. J. Sustain. Financ. Investig. 2017, 8, 1-25. [CrossRef]

115. Rola-Rubzen, M.F.; Paris, T.; Hawkins, J.; Sapkota, B. Improving Gender Participation in Agricultural Technology Adoption in Asia: From Rhetoric to Practical Action. Appl. Econ. Perspect. Policy 2020, 42, 113-125. [CrossRef]

116. Suvedi, M.; Ghimire, R.; Kaplowitz, M. Farmers' participation in extension programs and technology adoption in rural Nepal: A logistic regression analysis. J. Agric. Educ. Ext. 2017, 23, 351-371. [CrossRef]

117. Doss, C.R. Designing Agricultural Technology for African Women Farmers: Lessons from 25 Years of Experience. World Dev. 2001, 29, 2075-2092. [CrossRef]

118. Mwalupaso, G.E.; Korotoumou, M.; Eshetie, A.M.; Alavo, J.-P.E.; Tian, X. Recuperating dynamism in agriculture through adoption of sustainable agricultural technology-Implications for cleaner production. J. Clean. Prod. 2019, 232, 639-647. [CrossRef]

119. Liu, E.M. Time to Change What to Sow: Risk Preferences and Technology Adoption Decisions of Cotton Farmers in China. Rev. Econ. Stat. 2013, 95, 1386-1403. [CrossRef]

120. Zheng, S.; Wang, Z.; Wachenheim, C.J. Technology Adoption among Farmers in Jilin Province, China: The Case of Aerial Pesticide Application. China Agric. Econ. Rev. 2019, 11, 206-216. [CrossRef]

121. Handschuch, C.; Wollni, M.; Villalobos, P. Adoption of food safety and quality standards among Chilean raspberry producers-Do smallholders benefit? Food Policy 2013, 40, 64-73. [CrossRef]

122. Janssen, E.; Swinnen, J. Technology adoption and value chains in developing countries: Evidence from dairy in India. Food Policy 2019, 83, 327-336. [CrossRef]

123. Mumtaz, S.; Parahoo, S.K. Promoting employee innovation performance. Int. J. Prod. Perform. Manag. 2019, 69, 704-722. [CrossRef]

124. Lindell, M.K.; Whitney, D.J. Accounting for common method variance in cross-sectional research designs. J. Appl. Psychol. 2001, 86, 114-121. [CrossRef]

125. Torabizadeh, M.; Yusof, N.M.; Ma'aram, A.; Shaharoun, A.M. Identifying Sustainable Warehouse Management System In-dicators and Proposing New Weighting Method. J. Clean. Prod. 2020, 248, 119190. [CrossRef]

126. Podsakoff, P.M.; MacKenzie, S.B.; Lee, J.-Y.; Podsakoff, N.P. Common Method Biases in Behavioral Research: A Critical Review of the Literature and Recommended Remedies. J. Appl. Psychol. 2003, 88, 879. [CrossRef] [PubMed] 